\title{
KUALITAS KARKAS TERNAK BABI GROWER YANG MENGGUNAKAN TEPUNG KULIT KOPI SEBAGAI PENGGANTI SEBAGIAN DEDAK PADA RANSUM
}

\author{
Magdalena S. Gerungan, Mien Th.R. Lapian*, J.A.D. Kalele, Zulkifli Poli
}

Fakultas Peternakan Universitas Sam Ratulangi Manado

\begin{abstract}
ABSTRAK
Penelitian ini dilaksanakan untuk mengetahui pengaruh penggunaan tepung kulit kopi dalam ransum pada babi fase grower terhadap bobot potong, panjang karkas dan persentase karkas. Lamanya penelitian adalah 52 hari yang menggunakan 16 ekor babi keturunan jenis Landrace. Metode penelitian adalah Rancangan Acak Kelompok dengan 4 kelompok berat badan sebagai ulangan dan 4 perlakuan level tepung kulit kopi ransum yaitu $25 \%, 50 \%, 75 \%$. Variabel penelitian adalah bobot potong, panjang karkas dan persentase karkas. Hasil analisa sidik ragam menunjukkan bahwa pengaruh perlakuan penggatian sebagian dedak halus pada ransum dengan tepung buah kulit kopi memberikan pengaruh yang berbeda tidak nyata $(\mathrm{P}>0,05)$ terhadap persentase karkas dan bobot potong . Rataan bobot potong yang dihasilkan adalah $76.68 \mathrm{~kg}$, rataan persentase karkas $63.80 \%$. Hasil analisis sidik ragam menunjukkan bahwa pengaruh perlakuan penggatian sebagian dedak halus pada ransum dengan tepung buah kulit kopi memberikan pengaruh yang berbeda sangat nyata $(\mathrm{P}<0,01)$ terhadap panjang kerkas ternak babi. Hasil uji lanjut dengan menggunakan BNT menunjukkan bahwa R0 dibandingkan dengan R1, R2 dan R3, memberikan pengaruh berbeda tidak nyata terhadap panjang karkas. Berbeda nyata terjadi
\end{abstract}

*Korepondensi (corresponding autor)

Email: lapian_linda@yahoo.com pada perlakuan antara R1 dan R2, demikian juga R1 dibandingkan dengan $\mathrm{R} 3$, dan R2 dibandingkan dengan R3 memberikan pengaruh yang tidak berbeda nyata terhadap panjang karkas. Berdasarkan hasil penelitian ini, dapat disimpulkan bahwa penggunaan tepung kulit kopi sebagai pengganti pakan dalam ransum pada taraf $25 \%$ meningkatkan panjang karkas ternak babi yang lebih panjang.

Kata Kunci : babi, bobot potong, panjang karkas dan persentase karkas, tepung kulit kopi.

\section{ABSTRACT}

EFFECT OF COFFEE SKIN FLOUR AS A SUBSTITUTE FOR RICE BRAN IN THE RATION ON CARCASS QUALITY OF GROWER PIGS. Research entitled effect of coffee skin flour in the ration of grower phase pig on slaughter weight, carcass length and carcass percentage have been done. Research conducted for 52 days using 16 Landrace pigs. Methods of randomized block design were used. Four replication as group of weight was used and treatments were four level of coffee skin flour of $0 \%$, $25 \%, 50 \%$, and $75 \%$. The research variables are slaughter weight, carcass length and carcass percentage. Results of statistical analysis showed that there was no significant difference between treatments and the percentage of carcasses and slaughter weight $(\mathrm{P}>0.05)$. The mean of 
slaughter weight is $76.68 \mathrm{~kg}$ and the average of carcass percentage is $63.80 \%$. Analysis of variance showed that there is highly significant difference $(\mathrm{P}<0.01)$ between treatments and the length of carcass. Further test by the least significance difference method indicates that there was no significant difference on carcass length between $\mathrm{R} 0$ and $\mathrm{R} 1, \mathrm{R} 2$ and $\mathrm{R} 3$. There was also no significant difference on carcass length between R1 and R2, R1 and R3, and R2 and R3. Based on these results, it can be concluded that the use of coffee skin flour as a substitution as much as $25 \%$ of in the ration can increase the length of the carcass.

Keywords: carcass length and carcass percentage, flour coffee skin, slaughter weight, pork.

\section{PENDAHULUAN}

Ternak babi merupakan salah satu ternak potong penghasil daging yang tidak kalah penting dengan ternak potong lainnya, yang dapat menunjang pemenuhan kebutuhan protein hewani. Pertumbuhan ternak babi tidak hanya ditentukan oleh faktor genetik, akan tetapi faktor manajemen pemberian pakan sangat diperlukan guna mendapatkan tampilan produksi yang baik. Bobot potong ternak babi sangat berhubungan dengan karkas yang akan dihasilkan. Penentuan bobot potong yang optimal mempunyai hubungan yang positif dengan proporsi karkas yang akan dihasilkan (Soeparno, 1992)

$$
\text { Menurut Whittemore }
$$
menyatakan bahwa kisaran berat karkas adalah sekitar tiga per empat dari bobot potong. Bobot potong optimum dapat dicapai jika terdapat interaksi antara jenis pakan yang diberikan, cara pemberian pakan, bangsa ternak, jenis kelamin dan kematangan seksual (Devendra dan Fuller, 1979) Karkas adalah bagian tubuh tanpa darah, kepala, kaki, bulu dan seluruh isi rongga perut, kecuali hati dan jantung. Pengkarkasan pada ternak potong khususnya ternak babi dilakukan untuk mengetahui kualitas karkas yaitu, bobot karkas, Panjang Karkas dan Presentase Karkas.

$$
\begin{array}{rrr}
\text { Kendala yang sering ditemui } \\
\text { adalah ketersediaan pakan sering }
\end{array}
$$
berfluktuasi harga salah satu dedak halus pada waktu tertentu sulit diperoleh dan mahal harganya dipasaran. Hal ini terjadi karena penggunaan dedak halus sering bersaing dengan kebutuhan ternak lain. Untuk itu dilakukan upaya pencarian bahan pakan alternative yang dapat menggantikan dedak halus.

Tepung kulit buah kopi cukup potensial untuk digunakan sebagai bahan pakan. Tepung kulit buah kopi memiliki kandungan zat makanan yang cukup baik untuk dijadikan ransum pengganti, kandungan protein dan energi yang lebih tinggi dari dedak. Kandungan protein kulit buah kopi berkisar 11,18\%, serat kasarnya cukup tinggi yaitu dapat mencapai $21,74 \%$ dan nilai energi metabolisnya 2440 
$\mathrm{kkal} / \mathrm{kg}$ (Ruswendi, 2011). Selain itu limbah kopi mengandung pektin sejumlah 6,52\% (Murni et al,, 2008). Kulit buah kopi merupakan produk samping dari pengolahan buah kopi yang jika tidak ditangani lebih lanjut akan menimbulkan pencemaran dan hingga saat ini belum dimanfaatkan dengan baik (Diniyah et al., 2013; Raudah dan Ernawati, 2012). Daerah Sulawesi Utara terdapat beberapa sentra produksi kopi yang tersebar di beberapa daerah, di mana Kabupaten Bolaang Mongondow memiliki produksi kopi yang cukup besar. Potensi limbah kulit buah kopi yang besar ini memberikan peluang yang sangat besar untuk dimanfaatkan sebagai salah satu bahan pakan pengganti dedak halus dalam ransum ternak babi.

Berdasarkan uraian di atas maka telah dilakukan penelitian dengan tujuan until mengetahui pengaruh penggunaan kulit buah kopi sebagai pengganti dedak halus pada ternak babi fase grower.

\section{MATERI DAN METODELOGI PENELITIAN}

\section{Waktu Dan Tempat Penelitian}

Penelitian ini telah dilaksanakan di peternakan Kawangkoan. Dimulai pada fase grower sampai mencapai bobot potong (12-16 minggu) umur ternak babi, dengan 2 minggu periode pendahuluan

dan selanjutnya pengumpulan data. Penelitian dimulai pada bulan desember sampai bulan Februari.

\section{Materi Penelitian}

Penelitian ini menggunakan ternak babi betina dan jantan kastrasi sebanyak 16 ekor dengan kisaran bobot badan $30-58 \mathrm{~kg}$ (12-16 minggu), keturunan Landrace. Kandang yang digunakan dalam penelitian ini yaitu kandang percobaan 16 unit dengan ukuran 132x90x100cm. Setiap kandang dilengkapi dengan tempat makan dan minum. Lantai kandang terbuat dari beton dan antar unit dibatasi sekat kayu/bambu. Peralatan yang digunakan yaitu timbangan standar $5 \mathrm{~kg}$, timbangan ohaus $2600 \mathrm{gr}$ (untuk penimbangan pakan), timbangan ohaus $300 \mathrm{~kg}$ (untuk penimbangan ternak), ember, sekop, selang air, kalero, plastik dan sapu lidi. Ransum penelitian yang digunakan dalam percobaan konsentrat, tepung ikan, dedak, jagung. Yang menjadi perlakuan adalah tepung kulit kopi. Tepung kulit kopi yang digunakan dalam penelitian ini dijadikan sebagai pakan yang dicampur dengan pakan lainnya sebagai ransum untuk ternak babi.

Data hasil analisa susunan bahan pakan dapat dilihat pada Tabel 1, komposisi bahan pakan penelitian dapat dilihat pada Tabel 2, komposisi zat makanan dari ransum penelitian dapat dilihat pada Tabel 3. 
Tabel 1. Komposisi zat makanan dari pakan penelitian

\begin{tabular}{lllllll}
\hline Bahan pakan & Protein & Energi & SK & Lemak & Ca & P \\
\hline Jagung*** & 8,42 & 3182 & 2,15 & 5,17 & 0,22 & 0,6 \\
Konsentrat** & 39 & 3200 & 6 & 3 & 3 & 0,6 \\
Tepung ikan* & 27,49 & 3524 & 2,9 & 8,88 & 2,82 & 5,08 \\
Dedak**** & 12,9 & 2875 & 11,4 & 0,7 & 0,07 & 1,5 \\
Kulit Kopi* & 7,95 & 3619 & 33,6 & 1,03 & 0,21 & 1,08 \\
\hline
\end{tabular}

Ket :*)Hasil Analisa Laboratorium Institut Pertanian Bogor, 2016.
**) Hasil Analisis PT. CARGIL INDONESIA
***) Hasil Analisis Universitas Padjajaran, 2014.
****) Hasil Analisa Laboratorium Institut Pertanian Bogor, 2014.

Tabel 2. Susunan bahan pakan

\begin{tabular}{lllll}
\hline \multirow{2}{*}{ Bahan pakan } & \multicolumn{4}{l}{ Perlakuan } \\
\cline { 2 - 5 } & RO & R1 & R2 & R3 \\
\hline Jagung & 50 & 50 & 50 & 50 \\
Konsentrat & 12,5 & 12,5 & 12,5 & 12,5 \\
Tepung ikan & 12,5 & 12,5 & 12,5 & 12,5 \\
Dedak & 25 & 18,75 & 12,5 & 6,25 \\
Kulit kopi & 0 & 6,25 & 12,5 & 18,75 \\
\hline Total & 100 & 100 & 100 & 100 \\
\hline
\end{tabular}

Hasil perhitungan susunan bahan pakan perlakuan.

Tabel 3. Komposisi zat makanan dari ransum penelitian

\begin{tabular}{lllll}
\hline \multirow{2}{*}{ Zat-zat Makanan } & \multicolumn{4}{c}{ Persentase (\%) } \\
\cline { 2 - 5 } & R0 & R1 & R2 & R3 \\
\hline Protein & 15,75 & 15,44 & 15,13 & 14,82 \\
Energi & 3150,25 & 3196,75 & 3243,25 & 3289,75 \\
Serat kasar & 5,04 & 6,43 & 7,81 & 9,20 \\
Lemak & 4,25 & 4,27 & 4,29 & 4,31 \\
Ca & 0,86 & 0,86 & 0,87 & 0,88 \\
P & 1,39 & 1,36 & 1,33 & 1,31 \\
\hline
\end{tabular}

Hasil perhitungan dari Tabel 1 dan 2.

\section{Metode Penelitian}

Penelitian ini menggunakan Rancangan Acak Kelompok (Steel and Torrie, 1980) dengan 4 macam ransum (R0, R1, R2, R3) sebagai perlakuan dan 4 kelompok ternak babi sebagai ulangan.
Setiap kelompok terdiri dari 4 ekor. Perlakuan dalam penelitian adalah tepung kulit kopi yang dicampur dengan pakan lain sebagai ransum ternak babi dengan taraf pemberian, $25 \%, 50 \%$, $75 \%$. Jumlah perlakuan dalam penelitian ini adalah 4 
perlakuan dan 4 kelompok yang terdiri dari:

Perlakuan

R0 $=$ Dedak halus 100\% + Kulit kopi 0\%

$\mathrm{R} 1=$ Dedak halus $75 \%+$ Kulit kopi $25 \%$

$\mathrm{R} 2=$ Dedak halus 50\% + Kulit kopi 50\%

R3 = Dedak halus 25\% + Kulit kopi 75\%

Sedangkan kelompok berdasarkan bobot badan :

$\mathrm{B} 1=30-37 \mathrm{~kg}$

$\mathrm{B} 2=37,1-44 \mathrm{~kg}$

B3 $=44,1-51 \mathrm{~kg}$

$\mathrm{B} 4=51,1-58 \mathrm{~kg}$

\section{Prosedur Penelitian}

Babi fase grower dengan bobot badan sesuai kelompok ditempatkan secara acak pada masing-masing kandang secara individual. Setiap kelompok diberikan perlakuan tepung kulit kopi yang dicampurkan pada ransum, 25\%, $50 \%$ dan $75 \%$.

Pemberian makan diberikan ad libitum selama 52 hari, kemudian sisa makanan yang diberikan diukur pada pagi hari berikutnya. Ternak babi dipotong dan sebelumnya babi dipuasakan selama 24 jam kemudian ditimbang. Jumlah babi yang dipotong 16 ekor. Pemotongan dilakukan dengan menusuk bagian leher tepat didepan ujung tulang dada, dengan tujuan memotong vena jugularis. Sesudah pengeluaran darah selesai, bulu dibersihkan lalu babi dibakar kembali menggunakan api dari tabung gas lalu dilakukan pengeluaran organ-organ bagian dalam, ke empat kuku kaki dan kepala dipisahkan. Babi dipotong dengan cara horizontal. Selanjutnya data penelitian yang diperlukan diambil.

\section{Variabel Penelitian}

\section{Bobot Potong}

Bobot potong $(\mathrm{kg})$ adalah berat babi yang akan dipotong dilakukan penimbangan saat akan dipotong setelah dipuasakan selama 24 jam (Swatland, 1984).

\section{Panjang Karkas}

Panjang karkas $(\mathrm{cm})$ diukur dari tulang rusuk pertama sampai dengan bagian ujung depan pangkal tulang ekor aitch bone (Blakely dan David, 1982). Pengukuran dilakukan dengan menggunakan meteran.

\section{Presentase Karkas}

Presentase karkas (\%), dihitung dari bobot karkas (kg) dibagi dengan bobot potong (kg) dikalikan dengan 100\% (Lawrie, 2003).

\section{HASIL DAN PEMBAHASAN}

\section{Pengaruh perlakuan terhadap bobot potong (kg).}

Data hasil penelitian selama percobaan penggunaan kulit kopi dalam ransum ternak babi terhadap bobot potong tercantum pada Tabel 4 . 
Tabel 4. Rataan bobot potong $(\mathrm{kg})$ dari setiap perlakuan pada akhir perlakuan

\begin{tabular}{|c|c|c|c|c|c|}
\hline \multirow[t]{2}{*}{ Kelompok } & \multicolumn{3}{|c|}{ Perlakuan } & & \multirow[t]{2}{*}{ Rataan } \\
\hline & R0 & $\mathrm{R} 1$ & $\mathrm{R} 2$ & R3 & \\
\hline B1 & 70,50 & 67,00 & 57,39 & 56,50 & 62,85 \\
\hline B2 & 63,00 & 70,00 & 64,50 & 74,00 & 67,88 \\
\hline B3 & 89,50 & 89,00 & 82,50 & 89,00 & 87,50 \\
\hline B4 & 90,00 & 96,50 & 80,50 & 87,00 & 88,50 \\
\hline Rataan & 78,25 & 80,63 & 71,22 & 76,63 & 76,68 \\
\hline
\end{tabular}

Rataan hasil penelitian penggunaan tepung kulit kopi dalam ransum dengan taraf, $25 \%, 50 \%$, dan $75 \%$ terhadap berat potong ternak babi yaitu berkisar antara 56,50-96,50 $\mathrm{kg}$ dengan rataan yaitu $76,68 \mathrm{~kg}$. Hasil penelitian ini berbeda dengan hasil penelitian (Sather $e t$ al., 1980; Lapian et al., 2013) kisaran bobot badan yang dipasarkan 90-110 kg dengan rataan umum 94,02 kg. Hasil analisis sidik ragam menunjukkan bahwa penggunaan tepung kulit kopi sebagai pengganti sebagian dedak halus memberikan pengaruh yang tidak berbeda nyata terhadap bobot potong $(\mathrm{P}>0,05)$. Penelitian ini menggambarkan bahwa penggantian dedak dengan kulit kopi $25 \%$ belum menyebabkan perubahan bobot potong ternak babi. Tidak berubahnya bobot potong ternak babi yang diberikan tepung kulit kopi diduga karena setiap perlakuan mempunyai nilai nutrisi yang dikonsumsi hampir sama, selain itu juga disebabkan adanya kandungan protein dalam tepung kulit kopi yang dapat digunakan oleh ternak babi sebagai sumber asam amino untuk membentuk daging (Silalahi dan Sinaga, 2010). Bobot potong optimum dapat dicapai jika terdapat interaksi antara jenis pakan yang diberikan, cara pemberian pakan, bangsa ternak, jenis kelamin, dan kematangan seksual (Davendra dan Fuller, 1979).

\section{Pengaruh Perlakuan Terhadap Panjang Karkas}

Data hasil penelitian selama perlakuan penggunaan kulit kopi dalam ransum ternak babi terhadap panjang karkas tercantum pada Tabel 5.

Pada Tabel 5 menunjukan bahwa rataan panjang karkas ternak babi yaitu berkisar antara 33.59-85.40 cm dengan rata-rata yaitu 56,63. Hasil analisis varians menunjukkan bahwa perlakuan memberikan pengaruh yang sangat nyata $(\mathrm{P}<0,01)$ terhadap panjang kerkas ternak babi. Hal ini menunjukkan bahwa 
Tabel 5. Rataan panjang karkas (cm) dari setiap perlakuan pada akhir perlakuan.

\begin{tabular}{|c|c|c|c|c|c|}
\hline \multirow[t]{2}{*}{ Kelompok } & \multicolumn{3}{|c|}{ Perlakuan } & & \multirow[t]{2}{*}{ Rataan } \\
\hline & R0 & $\mathrm{R} 1$ & $\mathrm{R} 2$ & R3 & \\
\hline B1 & 44,41 & 49,58 & 33,59 & 38,98 & 41,64 \\
\hline B2 & 40,00 & 51,80 & 44,50 & 51,06 & 46,84 \\
\hline B3 & 82,34 & 85,40 & 60,70 & 80,10 & 77,14 \\
\hline B4 & 56,70 & 71,41 & 55,54 & 60,03 & 60,92 \\
\hline Rataan & $55.86^{\mathrm{ab}}$ & $64.55^{\mathrm{a}}$ & $48,58^{\mathrm{b}}$ & $57,54^{\mathrm{ab}}$ & 56,63 \\
\hline
\end{tabular}

Keterangan: Superskrip huruf yang berbeda pada baris menunjukkan hasil berbeda nyata $(\mathrm{P}<0,05)$

penggantian dedak dengan tepung kulit kopi sampai $75 \%$ memberikan pengaruh sangat nyata terhadap panjang karkas babi. Berbeda nyata terjadi pada perlakuan antara R1 dan R2, selanjutnya R0, R1 dan R3 memberikan pengaruh yang sama terhadap panjang karkas, demikian pula dengan R0, R2 dan R3 memberikan pengaruh yang tidak berbeda nyata terhadap panjang karkas. Dari hasil ini dapat disimpulkan bahwa penggantian dedak halus dengan kulit kopi sebanyak $25 \%$ memberikan efek yang lebih baik terhadap panjang karkas babi.

Hasil penelitian ini masih rendah dibandingkan dengan penelitian dari Siagian et al. (2005), yang mendapatkan data kualitas karkas babi dan analisis ekonomi dengan rata-rata $75,97 \mathrm{~cm}$. Panjang karkas erat hubungannya dengan panjang badan pada waktu hidup (Whittemore, 1980), hal ini sejalan dengan hasil penelitian yang diperoleh dimana bobot potong yang tertinggi pada penggantian dedak halus dengan tepung buah kopi taraf $25 \%$.

\section{Pengaruh Perlakuan Terhadap Presentase Karkas (\%)}

Data hasil penelitian selama perlakuan penggunaan kulit kopi dalam ransum ternak babi terhadap presentase karkas tercantum pada Tabel 6.

Tabel 6. Rataan persentase karkas (\%) dari setiap perlakuan pada akhir perlakuan.

\begin{tabular}{|c|c|c|c|c|c|}
\hline \multirow[t]{2}{*}{ Kelompok } & \multicolumn{4}{|c|}{ Perlakuan } & \multirow[t]{2}{*}{ Rataan } \\
\hline & R0 & $\mathrm{R} 1$ & $\mathrm{R} 2$ & R3 & \\
\hline B1 & 60,63 & 60,30 & 53,40 & 49,72 & 56,01 \\
\hline $\mathrm{B} 2$ & 54,18 & 63,00 & 59,98 & 65,12 & 60,57 \\
\hline B3 & 56,00 & 65,50 & 56,50 & 60,80 & 59,70 \\
\hline B4 & 77,40 & 86,85 & 74,86 & 76,56 & 78,92 \\
\hline Rataan & 62,05 & 68,91 & 61,19 & 63,05 & 63,80 \\
\hline
\end{tabular}


Rataan persentase karkas ternak babi yaitu berkisar antara 49,72-86,85\% dengan rataan yaitu $63.80 \%$. Hasil penelitian ini masih lebih rendah dibandingkan dengan hasil penelitian Goniwala et al. (2016) dan Aritonang (2011) yang menyatakan bahwa persentase karkas ternak babi sebesar $77,15 \%$.

Hasil analisis sidik ragam menunjukkan penggunaan tepung kulit kopi tidak berpengaruh nyata $(\mathrm{P}>0,05)$ terhadap presentase karkas. Walaupun hasil penelitian ini tidak berbeda nyata, namun jika dilihat dari Tabel 6 menunjukan bahwa penggantian dedak halus dengan tepung buah kulit kopi $25 \%$ terjadi peningkatan presentase karkas. Besarnya persentase karkas dipengaruhi oleh faktor tipe dan ukuran ternak serta penanganan ternak, lamanya pemuasaan, serta banyaknya kotoran yang dikeluarkan (Soeparno, 1992).

Penelitian ini mendapatkan hasil yang lebih tinggi dari pendapat USDA (1985) yaitu, persentase karkas babi dibagi menjadi beberapa kelas, kelas satu adalah $68-72 \%$.

\section{KESIMPULAN}

Berdasarkan analisis data dan pembahasan, dapat disimpulkan bahwa penggunaan tepung kulit kopi sebagai pengganti pakan dalam ransum pada taraf 25\% meningkatkan panjang karkas.

\section{DAFTAR PUSTAKA}

Aritonang, S.N. 2011. Pendugaan bobot karkas, presentase karkas dan tebal lemak punggung Babi Duroc jantan berdasarkan umur ternak. Jurnal Peternakan Indonesia. Vol. 13 (2): 120-124

Blakely, J. and H. B. David. 1982. The Sciences of Animal Husbandry. $3^{\text {rd }}$ Edition. Restorn Piblishing Company, Inc Reston A. Prenticehall Company, Virginia

Booth, W.D. 1995. Wild boar farming in The United Kingdom. 1995. Journal of Mountain Ecology 3: 245-248

Devandra, C and M.F. Fuller. 1997. Pig production and tropics. Oxford University Press.

Diniyah, N., Maryanto, A. Nafi, D. Sulistia, A. Subagio. 2013. Ekstraksi dan karakterisasi Polisakarida larut air dari kulit kopi Varietas Rabika (Coffea arabica) dan Robusta (Coffea canephora), Jurnal Teknologi Pertanian 14(2): 73-78.

Goniwala. A., M.Th.R. Lapian, Merri D. Rotinsulu, Jerny R.Bujung. 2016. Bobot potong panjang karkas bobot karkas dan presentase karkas babi grower dengan pemberian gula aren dalam air minum. Jurnal Zootek 36(2): 353-362

Lawrie RA. 2003. Meat Science. Second edition. Pergamon press. Oxford, 
New York, Toronto, Sydney, braunschweig.

Lapian, M.Th.R, Siagian, P.H, Manalu W., Priyanto, R. 2013. Carcass Qualities of finisher Pig Born To Superovulated Sows Before Mating. Jurnal Veteriner 14(3): 350-357

Ruswendi, 2011. Teknologi Pakan Berkualitas Untuk Sapi Potong. Balai Pengkajian Teknologi Pertanian Bengkulu.

Sather, A. P., A.H. Martin, R.W. Jolly and H.T. Fredeen. 1980. Alternative market weights for swine feed lot performance. J. Anim. Sci. 51:2836.

Siagian. P.H., S. Natasasmita, P. Silalahi. 2005 Pengaruh substitusi jagung dengan corn gluten feed (CGF) dalam ransum terhadap kualitas karkas babi dan analisis ekonomi. Media Peternakan 28(3): 100-108

Silalahi. M. dan S. Sinaga. 2010. Pengaruh Pemberian Tepung Kulit Buah Pepaya (Carica Papaya) Dalam Ransum Babi Periode Finisher Terhadap Presentase Karkas Tebal Lemak Punggung Dan Luas Urat Daging Mata Rusuk. Prosiding Seminar Nasional Teknologi Peternakan Dan Veteriner, Fakultas Peternakan Universitas Padjajaran, Bandung. Balai Pengkajian Teknologi Pertanian Lampung. Hal 680-685.

Soeparno. 1992. Ilmu dan Teknologi Daging. Gadjah Mada University Press. Yogyakarta

Steel, R.G.D. and J.H. Torie. 1980. Principles and Procedur of Statistic.

Swatland, H. J. 1984. Structure and Development of Meat Animals.
Prentice Hall Inc. Englewood Cliffs New Jersey.

USDA 1985. United States Standards for Grades of Pork Carcasses. United States Departement of Agriculture. 